\title{
Same-Sex Marriage and Civil Union in Same-Sex Relationships*
}

\author{
XIAO Peng \\ School of Foreign Studies, Zhongnan University of Economics and Law, Wuhan, China \\ LI Jue \\ Institute of International Law, Wuhan University, Wuhan, China
}

\begin{abstract}
About 40 years ago, same-sex marriage was still illegal around the world, but nowadays, partial countries have granted same-sex partners the right of marriage or established the civil union registration system, enabling same-sex partners to enjoy limited legal rights, such as succession and adoption. The legislative and judicial practice on recognition of foreign same-sex marriage and civil union in China is enunciated in the last section. The legal issues about characterization, application of law, public policy, and evasion of law were explored in detail in this section. Unlikely as it sounds that Chinese courts will recognize foreign same-sex marriage, it is believed that China should be more open to foreign same-sex relationships, especially when it is deemed as a preliminary question of major legal issues, such as adoption, succession, divorce, and parentage determination.
\end{abstract}

Keywords: same-sex marriage, civil union, public policy, limping marriage

\section{Introduction}

The legislative models of same-sex relationships can be divided into two categories: same-sex marriage and civil union. In same-sex marriages, homosexual couples are granted the same status of spouses as heterosexuals, though the two have different rights and obligations on legal issues, such as adoption. ${ }^{1}$ As for civil unions, same-sex partners enjoy the same marital rights in the form of registration except the title of spouse. $^{2}$

There is a legislative gap in same-sex marriage regulation between China and foreign countries. In practice, consular and judicial departments also hold a negative attitude towards protection of same-sex marriages. At the end of 2014, a Chinese male citizen, whose habitual residence was in San Francisco, married an American counterpart in California in accordance with the local law. Then, this couple applied to the Chinese consulate for a marriage certificate to purchase a house in China but was rejected because same-sex marriage is not recognized by Chinese Marriage Law (Ren, 2015, p. 72). In June 2014, Dai Weishen, the British consul general in Shanghai, held a same-sex wedding with his Chinese boyfriend, the legal effect of whose marriage in China,

\footnotetext{
* Acknowledgements: This research is supported by "the Fundamental Research Funds for the Central Universities”, Zhongnan University of Economics and Law (Grant Number 2722019JCT018).

XIAO Peng, Ph.D., lecturer, School of Foreign Studies, Zhongnan University of Economics and Law, Wuhan, China. E-mail: xiaopeng@zuel.edu.cn.

LI Jue, corresponding author, Ph.D. candidate, Institute of International Law, Wuhan University, Wuhan, China. E-mail: jessiejura@163.com.

1 The Civil Marriage Act in Canada and similar acts in the Netherlands, Spain, and Belgium; The Marriage (Same Sex Couples) Act in the UK and similar acts in Germany, Norway, Iceland, Sweden.

2 The Pacte Civil de Solidarité in France; the Defense of Marriage Act in Hawaii and Massachusetts, the US.
} 
namely whether this couple's rights and obligations should be protected by Chinese laws, however, is still open to debate.

China achieved the depenalization and decriminalization of homosexuality respectively in 1997 and 2001 (Jiang, 2016, p. 287). ${ }^{3}$ Chinese Taiwan enacted The Same-Sex Marriage Law on May 17, 2019, according to which same-sex partners can register marriages since 24 May, 2019. ${ }^{4}$ Besides, a mass of Chinese mainland college students are open-minded about homosexuality and even same-sex marriage (Zhang, Chi, Wu, S. S. Wang, \& J. Wang, 2012, p. 923). Personally, the author supports the recognition of foreign same-sex marriages and civil unions in China and advocates that same-sex couples should be granted legal status and ensured property rights protection, especially when it serves as a preliminary question.

The first two chapters of this article illustrated same-sex marriage and civil union's legislative backgrounds from the perspective of comparative law and the main arguments for and against same-sex marriage. The third chapter investigated the recognition of foreign same-sex marriage and civil union in China, especially when it comes as a preliminary question.

\section{Same-Sex Marriage: The Supreme Goal of Same-Sex Couples}

Netherlands, Belgium, and Spain respectively in 2001, 2002, and 2005 legalized same-sex marriages. The abovementioned three countries redefined marriage as a union between two natural persons of uncertain sex, and Spain in particular grants same-sex couples almost the same rights as heterosexual ones, including unrestricted rights of adoption. All three countries insist that the presumption of paternity in civil law does not apply to same-sex marriage; therefore, a paternal status can only be achieved through adoption in this relationship.

A series of countries and regions started to legalize same-sex marriage between 2005 and 2010, among which Canada, South Africa, Norway, Switzerland, Portugal, Iceland, and Argentina succeeded. France kept up with this trend and passed a bill in 2013 which allowed same-sex couples to get married. Some federal states, such as Mexico and the United States, also redefined marriage to legalize same-sex marriage, and now heterosexual and homosexual marriage is treated almost equal. ${ }^{5}$

Overall, the abovementioned countries have all undergone a long process before same-sex marriage being finally recognized. In the initial stage, they only granted same-sex partners partial property rights and same-sex marriage, which embodied full equality between homosexual and heterosexual couples, was the culmination of the campaign. Nevertheless, married same-sex couples cannot automatically obtain all the rights enjoyed by heterosexual couples despite legalized homosexual marriage in the abovementioned countries or regions. To sum up, the differences between the two are mainly reflected in the following three aspects.

First, the right of same-sex couples to establish a family is limited. Based on the laws of the aforementioned countries, the main difference between heterosexual and homosexual marriage is whether the two types of couples can form families that are recognized by domestic law through marriage. In fact, countries

\footnotetext{
${ }^{3}$ In 1997, all the crimes of hooliganism, such as sodomy, were abolished in the Chinese Criminal Law in 1997. In April, 2001, the new Chinese Classification and Diagnostic Criteria of Mental Disorders removed homosexuality from its list of mental illnesses.

${ }^{4}$ See Chinese Taiwan passed the "special law" on same-sex marriage, same-sex couples can register their marriages under the law.China.com, https://news.china.com/domestic/945/20190517/35921289.html (last visited May 17, 2019).

5 See same-sex marriage laws. National Conference of State Legislatures, http://www.ncsl.org/research/human-services/same-sex-marriage-laws.aspx (last visited Jan. 10, 2019).
} 
that allow same-sex couples to get married are not fully prepared for their families and parent-child relationships. Therefore, same-sex couples still prefer civil union registration despite legalized same-sex marriage in many countries, because this union not only recognize the bond between the couple but also create a legally recognized family relationships, including the parent-child relationship. This legal issue was discussed in detail in the next section of civil unions.

Second, how same-sex marriage and opposite-sex marriage are viewed, either equally or unequally, varies across countries. Simply put, a country cannot guarantee that marriages recognized by its laws will also be acknowledged in other countries and within its jurisdiction, while it can decide whether to recognize the validity of a foreign same-sex marriage. Some countries might impose limitations on same-sex marriage. For example, same-sex couples are subject to more restrictions than heterosexuals in the Netherlands. Denmark has stipulated similar restrictions through the Partner Registration Act. Same-sex marriage raises several legal issues in the field of private international law, such as polygamy, limping marriage, and surrogacy that conflict with domestic laws and regulations. As the recognition of foreign same-sex marriage and civil union will be examined in the fourth part, it will not be detailed here.

Finally, differences also manifest themselves in the forms of marriages. The major dispute is whether same-sex weddings should be performed by church chaplains and follow the same ceremonies as heterosexual weddings. In countries where same-sex marriage is legalized, marriage ceremonies are usually performed by the clergy, who might refuse to do the same for homosexuals for the sake of their religious beliefs, which is understandable. But lawmakers also realize that the existing discriminatory practices should not be reinforced by these people for religious reasons. In light of equality, same-sex couples should also be blessed by the priests. In a country where marriage must strictly follow a secular process, the decision to separate church chaplains from marriage ceremonies makes little sense compared with political compromise. However, regarding same-sex marriage as one of the mainstream relationships has become a trend, and some of the symbolic rituals of marriage might be gradually abandoned in most cases. In addition, many priests have called for different marriage ceremonies and staffs in charge of same-sex marriage registration.

\section{Civil Union That Is Equal to Marriage}

Since the late 20th century, many countries have enacted or modified laws to grant same-sex couples rights or benefits similar to those of heterosexuals. In general, there are three models for recognizing and managing same-sex partnerships.

\section{Civil Union That Is Equal to Marriage}

Although some countries did not recognize same-sex marriage, they legalized the system of civil union and rendered it equal to marriage. Denmark and the United Kingdom exemplified civil union before they legalized same-sex marriage.

In 1989, Denmark became the first country to establish the civil union registration system, which only applied to same-sex couples. Originally, parental rights were not included in the law but now registered partnerships have almost all the same qualities as marriage, including adoption, assisted reproductive technology, and so on. Up to now, the main difference between married couples and registered same-sex partners lies in the forms of marriage. Clearly put, same-sex weddings can be performed either in a religious or civil manner, but only registered in the latter way because the same-sex partnership registration system is strictly under a civil bill. 
Similarly, the United Kingdom adopted civil union which was equal to marriage in 2005 and passed The Same-Sex Marriage Act in 2014. What it takes to get married is very similar to that of civil union, and same-sex partners married in foreign countries are recognized as civil unions in England.

In conclusion, couples who form civil unions are not in a marital status and have no wedding ceremonies, but they can form families through adoption because they enjoy the same paternal rights as those who get married. Therefore, we call it civil union which is equal to same-sex marriage. However, couples registered as civil unions can also choose to get married, which is stipulated in almost all the subsequent laws, because the difference between the two is no more than the form.

\section{Civil Union That Is not Counted as Family}

Many countries manage same-sex relationships through civil unions, granting most rights to same-sex partners except the right of adopting children to form families, which are therefore deemed as civil unions that are not counted as families.

Although civil unions are protected by the laws of Australia, Austria, and New Zealand, the partners usually do not enjoy the right of adoption and cannot or are restricted to use assisted reproductive technology (ART) under family laws. In 2008, Australia's federal regions expanded the existing laws to treat opposite-sex and same-sex partners equally. In fact, however, only the Australian capital, Tasmania and Queensland allow same-sex couples to adopt children and women are still restricted to use ART.

New Zealand promulgated The Civil Unions Act in 2004, which applied to both same-sex and opposite-sex partners, and then passed The Same-Sex Marriage Act in 2013; the married same-sex couples were allowed to convert their relationships into civil unions without divorce. The most important difference between marriage and civil union was that the latter cannot adopt children.

Germany has adopted an approach similar to Denmark, namely setting up a parallel management department targeting same-sex couples and limiting their right of adoption. Germany established and implemented the legal system of civil unions in 2001, but lawmakers wanted to show that it is different from marriage. Under civil union laws, two natural persons of the same-sex can register as a civil union by declaring that they will cohabit. Co-adoption and the employment of ART are still banned, but step-children are allowed to be adopted for same-sex partners.

Switzerland passed The Partnership Registration Act in 2004, which allowed same-sex couples to register as civil unions. Under the act, registered partners are virtually indistinguishable from married ones in many areas, such as succession, taxes, hospital visits, property rights, social insurance, pensions, immigration, civil rights and obligations, rental housing, employment, and civil and criminal litigation. Besides, Swiss civil union and marriage can be registered in front of the same church deacon and recorded in the same files (American Bar Association, 2004, p. 408). Hungary and Austria also adopted approaches similar to Germany and Switzerland.

In short, the civil unions described above do not differ substantially from marriage in any other way except family establishment and adoption.

\section{Incomplete Civil Union}

Although some countries have also enacted or amended laws to recognize the civil union of same-sex partners, they only grant limited rights for same-sex partners, mainly property rights, compared with the abovementioned countries. 
First, countries such as Colombia, Uruguay, and Croatia modified their laws to formally legalize same-sex partners and granted them limited rights. In Colombia, registration of civil union or other similar system has not opened to same-sex partners and both heterosexual and homosexual couples who meet certain legal conditions are considered to be combinations of de facto marriages and enjoy rights pertaining to healthcare, pensions, and civil and criminal law. Uruguay began regulating heterosexual lovers who were unmarried in the late 1980s. More specifically, some laws have recognized "unmarried cohabitation" and granted them rights of succession under special circumstances and decision on a partner's medical treatment. Croatia enacted The Civil Unions Act in 2003, which recognized partial rights of same-sex partners. According to the law, civil union refers to the life combination of two persons of the same-sex who are unmarried, have no heterosexual relationships or have not established other same-sex families, and continue to live together for at least three years on the basis of the principles of mutual equality, mutual respect, mutual help, and emotional maintenance. The bill does not require civil unions to be registered but stipulates that the partners in a civil union have the right to own property of each other and to mutual assistance. The Czech Republic passed The Partnership Registration Act in 2006, which specifically regulated and protected same-sex partners by law. Same-sex partners do not have the right of succession or co-ownership of property, and do not extend their kinship relations as a result of the civil union registration. Under special circumstances, nonetheless, same-sex couples are entitled to assistance and corresponding property rights from each other. In 2010, the Irish President signed both The City Marriage Act and The Special Rights and Responsibilities Act for unmarried cohabitants, the latter of which applies only to same-sex partners and provided them with property rights, succession rights, pensions, etc.

\section{Recognition of Foreign Same-Sex Relationships in China}

Same-sex couples might ask for the recognition of foreign same-sex marriage or civil union in China out of two reasons. First, as a preliminary question, recognition of these relationships could help to solve major legal issues, such as succession, adoption, or parentage determination. Second, those couples crave for the confirmation of identity, which obviously violates the gender requirement in Marriage Law of the People's Republic of China of 2001 (Chinese Marriage Law) and public order and good customs in General Provisions of the Civil Law of the People's Republic of China of 2017 (GPCL of 2017). The abovementioned two categories were explored in detail in this section.

\section{Recognition as a Major Legal Issue}

Firstly, should the foreign same-sex relationships be portrayed as marriage or partnership? As far as the author is concerned, same-sex marriage is tantamount to a marital relationship since it consists of the same elements, such as love, responsibility, rights, and obligations as the heterosexual marriage. Moreover, the civil union should be classified as co-habitation relationship between heterosexual partners, although co-habitation is not a de facto marriage any more in China.

Secondly, the case is foreign-related since the same-sex relationship in question was connected abroad according to foreign law, and the parties sometimes include foreigners, which means the Law of the People's Republic of China on Choice of Law for Foreign-related Civil Relationships of 2010 (LAL) should be applied in these cases.

Thirdly, according to Article 21 of LAL, conditions for marriage shall be governed by laws of the common habitual residence of both parties concerned. In the absence of a common habitual residence, common 
lex patriae of the parties shall apply. Where the parties are of different nationalities, and the parties get married in the habitual residence or country of nationality of either party, laws of the place of marriage shall apply. Therefore, the foreign law of common habitual residence of both parties or the place of marriage will be applied in such recognition cases, and in most situations, same-sex relationship is lawful in the abovementioned foreign law.

However, does this mean that foreign same-sex relationships shall be recognized China? The answer is negative. According to Article 5 of LAL, laws of the People's Republic of China shall apply where the application of foreign laws will undermine social and public interests of the People's Republic of China. Recognition of same-sex relationships in China violates Chinese public policy, since same-sex marriage and civil union are not lawful in China yet according to Article 5 of Chinese Marriage Law that marriage must be based upon the complete willingness of both man and woman, rather than same-sex partners. Therefore, the foreign law could not be applied in the case of recognition of foreign same-sex relationships, and lex fori should be applied, suggesting that the foreign same-sex marriage or civil union could not be recognized since it violates Chinese national statutes.

Besides, there is another safety valve, evasion of law, preventing foreign same-sex relationships from being recognized in China. It is commonplace that same-sex parties would travel abroad for marriage or civil union registration, which turns to limping marriage when they return to their homeland. According to Article 11 of Interpretation of the Supreme People's Court on Certain Issues Concerning the Application of the LAL I of 2012 where one of the parties concerned intentionally creates a connection point in foreign-related civil relations so as to avoid being subject to the mandatory provisions of the laws and administrative regulations of the People's Republic of China, the people's court shall determine that foreign laws cannot be adopted. Therefore, Chinese courts will not apply the foreign law which is chosen by the created connecting factors, and the same-sex relationships could not be recognized.

In general, both foreign same-sex marriages and civil unions are unlikely to be recognized in China since they breach Chinese public policy and evasion of law in private international law area. However, when it comes to recognition as a preliminary question, the answer might be opposite because the legal value that Chinese courts want to protect differs, and this was detailed in the next section.

\section{Recognition as a Preliminary Question}

The foreign same-sex couples applying for recognition sometimes aim to solve other disputes, such as adoption, succession, and divorce. The applicable law depends on the character of the legal issue.

For adoption, the people's court is inclined to protect the stability of adoptive relationships. According to Article 28 of LAL, the validity of adoption shall be governed by laws of the habitual residence of the adopter at the time of adoption, which means the applicable law could be Adoption Law of the People's Republic of China of 1998 (Adoption Law) or the law of the habitual residence of the same-sex partners. If the both parties are Chinese, according to Article 10 of Adoption Law, where a person with spouse adopts a child, the husband, and wife shall adopt the child in concert, indicating that same-sex couples cannot adopt children in China since there is no husband or wife in their relationships. However, if the both parties are foreigners and adoption is lawful for same-sex couples in the habitual residence of the parties, then the adoptive relationships will be recognized by the people's court. The judge of the people's court may exercise discretion in specific cases to protect the best interest of children and the stability of adoptive relationships. 
In terms of succession, LAL adopts a scission system over the issue of succession, which means laws applicable to real properties and personal properties could be different. According to Article 31 of LAL, statutory succession shall be governed by laws of the habitual residence of the decedent at the time of death, provided that statutory succession to real properties shall be governed by lex situs of the properties. The partner of the decedent could be statutory successor with first priority if the applicable law is the law of the habitual residence of the decedent where the same-sex marriage or civil union is lawful.

However, when it comes to succession of real properties, the applicable might be Law of Succession of the People's Republic of China of 1985 or foreign lex situs of the properties, which means that the partner of the decedent may not have the right of succession. This issue could be properly solved by testamentary succession, since Chinese legislators protect autonomy of parties to make a will and validate it to the greatest extent. According to Article 33 of LAL, the validity of a will shall be governed by laws of the habitual residence or lex patriae of the testator at the time of death or will creation, which means the law applicable could be the foreign law which stipulates that same-sex partner is the legal spouse and has the right of succession of first order.

The applicable laws are different in the cases of contested divorce and uncontested divorce. According to Article 27 of LAL, in the case of a contested divorce, lex fori shall apply, while according to Article 26 of LAL, in the event of an uncontested divorce, the couple concerned may choose to apply laws of the habitual residence or lex patriae of either party. Where the couples have made no such choice, laws of their common habitual residence shall apply. In the absence of a common habitual residence, the common lex patriae of the couple shall apply. Where the couples are of different nationalities, laws of the place where the agency handling the divorce formalities is located shall apply. In general, the possibility of applying Chinese Marriage Law is high, which means that same-sex marriage is unlawful and the same-sex relationship is unable to be ended by Chinese court.

Another occasion is that foreign partners directly apply for recognition judgments on divorce of same-sex marriage. Chinese courts may refuse because according to Art. 2 of Provisions of the Supreme People's Court on Issues Concerning Acceptance by People's Courts of Applications for Recognizing Divorce Judgments of Foreign Courts of 2000, in the event that a foreign citizen applies for recognition of a divorce judgment of a foreign court, the people's court shall refuse to accept the application but may notify the applicant to directly apply for remarriage registration to a marriage registration office if the former spouse is a foreign citizen.

In general, in the case of adoption, whether Chinese courts recognize its validity depends on the place of adoption and the habitual residence of the foreign same-sex partners. In the case of succession, the author strongly suggests that same-sex partners should make a will before coming to China, since this relationship is unlawful in China and they need to strive to protect their rights. In the case of divorce, there is little chance that Chinese court will grant divorce to foreign same-sex couples, and appealing to a court to start divorce proceedings is not necessary since same-sex marriage is not valid in China throughout.

\section{Conclusion}

Although neither same-sex marriage nor civil union is legalized in China, it is believed by the author that the people's court should endeavor to protect the rights of foreign same-sex couples, especially in cases when the validity of same-sex marriage become the preliminary question.

The people's court should not rely too much on the safety valve. First, evasion of law should be limited under the circumstances that the parties travel abroad just to evade the mandatory rules in China and get 
married regardless of Chinese Marriage Law. Second, if the parties have got married or registered as civil union in foreign countries and then come to and reside in China, the court should refuse the parties' application on recognition of same-sex relationships, since it violates the applicable law, i.e., Chinese Marriage Law. However, if the parties do not have a common habitual residence, the law of the place where the marriage is concluded should be applied and the marriage might be recognized. Finally, if the recognition of foreign same-sex relationship is a preliminary question, the author suggests that the people's court should recognize its validity moderately, providing that the major dispute is about money in China, and the recognition does not compromise Chinese public policy and interests.

Both domestic and international same-sex partners have to face uncertain situation of identity and property. Like in any other countries, there is a gap between law and reality in China. Many factors have contributed to the present unsatisfactory situation and same-sex marriage is more of a moral and ethical problem than of law. The author believes that Chinese people are becoming more and more open-minded, therefore, same-sex marriage and civil union, which meet the real demand and reflect social reality, will be accepted by more people, and these legal issues could be spontaneously solved.

\section{References}

American Bar Association. (2004). A white paper: An analysis of the law regarding same-sex marriage, civil unions, and domestic partnerships. Family Law Quarterly, 38(2), 339-425.

Jiang, Y. (2016). An introduction to forefront issues in family law. China: Law Press.

Ren, Z. H. (2015). China doesn't recognize the validity of “same-sex marriage”-From the perspective of practices in consulates at home and abroad. World Affairs, 16, 72.

Zhang, P. C., Chi, X. L., Wu, M. X., Wang, S. S., \& Wang, J. (2012). Status and influencing factors of attitude toward LGBT among college students. Chinese Journal of Public Health, 28(7), 921-923. 